\title{
The Arrangements of Online Dispute Resolution as an Alternative Resolution of the Electronic Commerce Transactions in Indonesia
}

\author{
RAHMADI INDRA TEKTONA \\ AYUDYA RIZQI RACHMAWATI
}

\begin{abstract}
The article is motivated by the practical preference from conventional alternative dispute resolution to online dispute resolution as information and communication technology progresses, especially in electronic commerce. It aims to provide a concept about the fore on regulations of online dispute resolution as an alternative dispute resolution applicable to electronic commerce in Indonesia. This normative legal research which uses statute and comparative approach provides an explanation on the importance of regulating online dispute resolution so as to give legal certainty and legal protection to consumers of electronic commerce.
\end{abstract}

Keywords: Arrangement; online dispute resolution; electronic commerce

\section{INTRODUCTION}

Electronic commerce (hereinafter referred to as e-commerce) refers to the practice of engaging in trade by using electronic communication technology. It can further be interpreted as commercial activities carried out through the exchange of information which is created, stored or communicated through electronic, optical or analog media, including EDI (Electronic Data Interchange), e-mail, and so on. ${ }^{1}$ Onno W. Purbo and Aang Arif Wahyudi bring out another definition of e-commerce that states that e-commerce is a broad scope of technology, processes and practices that can conduct business transactions without using paper as a means of transaction mechanism. This can be done in various ways such as by e-mail or World Wide $\mathrm{Web}^{2}$

In connection with the explanation above, the e-commerce industry currently has developed very rapidly despite the slow pace of the Indonesian economy. The rapid development of e-commerce has not been balanced with the increase of the consumers' awareness and knowledge of their rights and obligations. Consumers have always been the object of business activity by the business actors to reap profits through promotional tips, sales method, and the application of harmful standard agreements. More specifically, in the electronic commerce transactions, consumers are often faced with the irresponsible behavior of the business actor.

The irresponsible behavior of business actors causes disputes between them and the consumers. Dispute cases that often occur in the e-commerce transaction are that there is a mismatch between the images of goods shown in the online stores and those sent to and received by the consumers ${ }^{3}$ Another action that harms consumers is that the e-commerce business actor intentionally does not deliver goods that consumers have purchased to obtain unilateral profits. ${ }^{4}$ Losses on e-commerce transactions arise due to an imbalanced negotiation process between the parties caused by the adoption of standard contracts.

Consumers as the injured party will convey their dissatisfaction to the business actors. In this case, if the second party can respond and satisfy the first party, the conflict is resolved. On the other hand, if the reaction of the second party shows different opinion or has different values, a dispute case can easily occur. ${ }^{5}$ In e-commerce transactions, there is no clear process regarding the dispute resolution mechanism that can be taken.

Non-face, borderless, and paperless e-commerce transactions provide new challenges in the dispute resolution process. Regarding the implementation of e-commerce transactions that have characteristics in terms of ease and speed, it is hoped that if an 
e-commerce transaction dispute occurs, it can also be accommodated in the dispute resolution process. In addition, the legal relationship on the e-commerce transactions is established from agreements made through the internet. The parties that carry out legal relations come from all regions of Indonesia and even from various parts of the world. Thus, this is where a dispute resolution method is needed to bridge various legal interests with the different, efficient, effective and low cost systems. ${ }^{6}$ One of the breakthroughs is the use of alternative model of electronic dispute resolution, known as Online Dispute Resolution (it is later called as ODR). This model enables the disputing parties to resolve the cases wherever they are. The online communication methods that can be used include: e-mail, instant messaging, chat, threaded discussion, video / audio streams, teleconference, and video conference. ${ }^{7}$ Pablo Cortes comes up with the ODR definition in his journal as follows: ${ }^{8}$

"Online dispute resolution in the consumer context refers to the use of ICT tools and methods (usually alternative to the court system) employed by businesses and consumers (B2C) to settle conflicts that arise out of economic transactions between the parties, particularly in e-commerce".

Related to that, it is necessary to explain who the parties are that have the right to regulate the internet. This is related to the fact that many disputes that occur and are resolved through ODR are those that happen due to online activities on the internet, one of which is electronic transaction disputes. ODR mechanism frees the determination and the use of legal options, but most of dispute resolution agreements are made in a standard article or known as a Standard Contract. ${ }^{9}$

ODR requires a set of completeness and adequate internet access so that the ODR process can run smoothly and is supported by a website that is integrated with a database application to accommodate the incoming requests, a list of arbitrators and / or mediators, as well as the necessary regulations regarding the applications to run an ODR. ${ }^{10}$

In this regard, an arrangement of ODR application is needed, starting from the ODR implementing agency, the method of dispute resolution, mechanism and stages of dispute resolution, and the outcome of the dispute decision. This needs to be done so that ODR can be used safely without inciting distrust in the users of electronic commerce transactions. Based on the background as outlined above, the main question is "What are the future arrangements of the online dispute resolution as an alternative to settle the electronic commerce disputes in Indonesia?"

\section{MATERIALS AND METHODS}

The research method used in this paper is normative research, which explain and describes in detail the arrangements of online dispute resolution as an alternative resolution of the electronic commerce transactions in Indonesia. Normative legal research is generally called library research, which focuses on primary and secondary material analysis. ${ }^{11}$ Soejono and Abdurrahman refer to normative legal research as doctrinal research, namely: research whose object of study consist of statutory documents and library materials. ${ }^{12}$ This research also provides a systematic analysis about the rule of law regulating specific areas of law, analyses the relationship between one rule of law with the other ones, describes the parts that are difficult to understand from a rule specific laws, maybe even including predictions of the development of the rule of law certain future. ${ }^{13}$ Regarding the writing of this article, the rule of law is used by contain provisions about the online dispute resolution so that it can be analysed the arrangements of online dispute resolution as an alternative resolution of the electronic commerce transactions.

In practice, some approaches are adopted, namely legislative and comparative approaches. The legal approach is made by reviewing all the laws and regulations about the issues of law presented. ${ }^{14}$ The result of the case was later used as arguments to resolve the legal issues encountered. Accordingly, in the writing of this scholarly paper, a legal approach to review the laws relating to the implementation of online dispute resolution, as well as matters pertaining to the legalization of online dispute resolution as an alternative dispute resolution for consumer of e-commerce transaction, and the rule used by Indonesia's positive law is Law Number 30 of 1999 concerning Arbitration and Alternative Dispute Resolution. Meanwhile, matters relating to electronic transactions are 
regulated in Law of the Republic of Indonesia Number 19 of 2016 concerning the amendment of Law Number 11 of 2008 about the Electronic Information and Transactions (it is later called as UU-ITE). Furthermore, trading activities are regulated in Law Number 7 of 2014 concerning Trade, and Government Regulation Number 80 of 2019 about the Trade through Electronic Systems (it is later called as PP PMSE). The comparative approach is the approach was used to compare the laws of one country, with the laws of another country regarding similar matters. ${ }^{15}$ In this article, there is also comparative approach used to elaborate the law in Indonesia in accommodating online dispute resolution and explaining the similarities and difference with the application of online dispute resolution China (China International Economic and Trade Arbitration / CIETAC) and European Union (European Commission / EC).

\section{THE DISCUSSION}

Some countries in the world such as China, the United States, and other European Union countries have implemented ODR practices in disputes arising from the electronic transactions. In Indonesia, the regulation regarding Alternative Dispute Resolution is regulated through Law Number 30 of 1999 concerning Arbitration and Alternative Dispute Resolution. Meanwhile, matters relating to electronic transactions are regulated in Law of the Republic of Indonesia Number 19 of 2016 concerning the amendment of Law Number 11 of 2008 about the Electronic Information and Transactions (it is later called as UU-ITE). Furthermore, trading activities are regulated in Law Number 7 of 2014 concerning Trade. The three laws basically have provided the online dispute resolution and in "lex generale" basis, they can be the basic of resolution through ODR in Indonesia.

Initially, the implementation of ODR in Indonesia still raises several problems, because Law Number 30 of 1999 concerning Arbitration and Alternative Dispute Resolution explicitly does not yet regulate the online dispute resolution (ODR). However, after the Indonesian government in November 2019 issued a Government Regulation Number 80 of 2019 about Trade through Electronic, the implementation of ODR in Indonesia already has a legal basis as it is stated in Article 72 paragraph (2) PP of PMSE as follows:

"The PMSE dispute resolution mentioned in paragraph (1) can be held electronically (online dispute resolution) based on the statutory provisions."

The article provides the basis for the ODR implementation in Indonesia, although this government regulation has not specifically appointed an institution as an ODR organizer in Indonesia. In addition, the PMSE PP also regulates the legal options and the choice of dispute resolution forums if the electronic commerce transactions involve parties from different countries.

The application of ODR has various forms of methods. They are online negotiation, online mediation, and online arbitration. These three methods are generally used by countries that have implemented ODR such as the European Union and China. Of the 3 (three) ODR implementation methods above, if you see the explanation of Article 72 paragraph (2) of the PMSE PP, the form of online dispute resolution that can potentially be applied in Indonesia is online mediation. The following is the explanation of Article 72 paragraph (2) PP PMSE:

"Basically, the electronic dispute resolution (online dispute resolution) returns to the agreement among parties. This can take the form of electronic mediation organized by the supporting professionals such as advocates or mediators, the accredited online arbitration institutions, or through the government agencies that have the authority for that."

The choice of online mediation as an ODR method will be applied in Indonesia because it is considered to be the most effective way to overcome communication problems that are limited by the distance and time of the parties in e-commerce transactions. This online mediation system summarizes the way mediation works by face to face which is directly transformed into a meeting via video connection using several document transfer features electronically.

This online mediation process is considered to facilitate the meeting of the disputing parties, if there is one party that is unable to attend the mediation meeting. So that, there is no longer reason that dispute resolution costs an expensive trip, due to the fact that the process is facilitated by technology through video call or video conference. ${ }^{16}$ 
The choice of online mediation as an ODR method applied in Indonesia does not escape the consideration that the process of dispute resolution in mediation is assisted by the third parties, namely mediators who are impartial and able to work with the disputing parties to help obtaining an agreement that satisfies the disputing parties. Besides, mediation is also chosen because the resulting decisions can be directly carried out without having to ask for authorization and the decision applies regardless of time.

The online mediation procedure begins with the parties submitting a file by filling out an online form that helps identify the problem and provides a possible solution. The other party will be notified by e-mail and respond to the case. Communication between the two parties will be displayed in a personal case page on the website. Then the parties negotiate directly. During the negotiation process, the parties communicate with each other in secret. If the negotiation does not reach any agreement, the market place will assign a mediator to help the parties reach it. ${ }^{17}$ The flow of consumer dispute resolution through ODR will be briefly described in the form of the following chart.

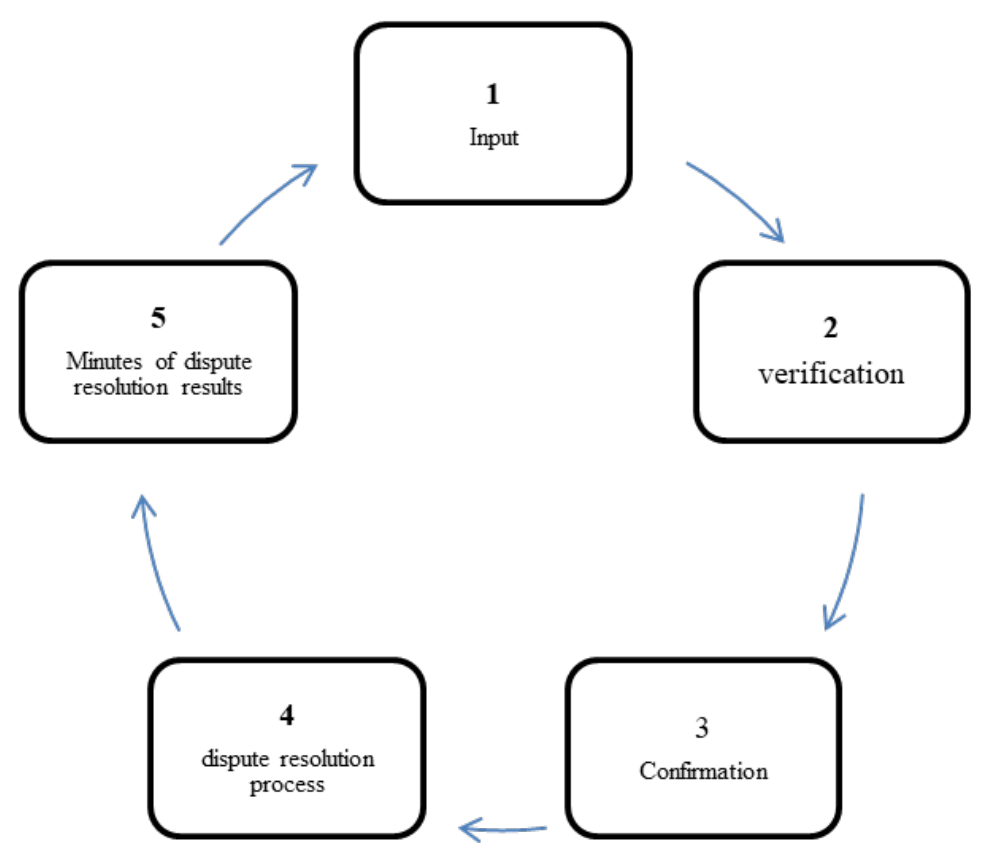

FIGURE 8.1 The electronic dispute resolution flow chart

The issuance of the PP PMSE does not necessarily provide a concrete solution to the ODR implementation. This is due to the fact that Indonesia does not yet have a special institution that has the authority to implement the ODR system in handling consumer disputes arising from the use of e-commerce. Based on the elucidation of Article 72 paragraph (2) PP PMSE, the online dispute resolution is held by the professionals such as advocates or mediators, through an accredited online arbitration institution or a government agency that has the authority for that. In relation to that, it can be seen that ODR administrators can be non-governmental institutions that have been accredited and the government agencies authorized to conduct dispute resolution. Related to government agencies that have the authority to implement ODR, the government can optimize the role and function of the Consumer Dispute Resolution Agency (BPSK). BPSK is considered to have a great opportunity to be able to implement ODR in resolving disputes arising in e-commerce transactions. This can be reviewed based on the discussion covering several things namely BPSK's competence. BPSK's competence shows that e-commerce dispute resolution can be resolved at BPSK as long as it concerns the consumer as one of its parties. 
Furthermore, the process of dispute resolution through ODR can use references from countries that have implemented the ODR itself. In this case, the European Union and China are a number of countries that already have ODR holding devices in the settlement of e-commerce transaction disputes, which is through the European Commission (EC) and the China International Economic and Trade Arbitration Association (CIETAC). The following table is the explanation of differences in the ODR implementation organized by CIETAC and EC.

TABLE 8.1 The Differences in the Implementation of Online Dispute Resolution between China (China International Economic and Trade Arbitration Commission / CIATEC) and the European Union (European Commission)

\begin{tabular}{|c|c|c|c|}
\hline Number & $\begin{array}{l}\text { Distinguishing } \\
\text { Factor }\end{array}$ & $\begin{array}{c}\text { China } \\
\text { (China International Economic and Trade } \\
\text { Arbitration Commission) }\end{array}$ & $\begin{array}{c}\text { European Union } \\
\text { (European Commission) }\end{array}$ \\
\hline 1. & Institutional & $\begin{array}{l}\text { The CIETAC is a permanent arbitration institution } \\
\text { that is specifically dealing with economic and } \\
\text { trade disputes. }\end{array}$ & $\begin{array}{l}\text { The EC is a subsidiary organ of the European } \\
\text { Union, which represents the EU's overall } \\
\text { interests in Trade activities. }\end{array}$ \\
\hline 2. & $\begin{array}{l}\text { Legal Basis } \\
\text { for ODR } \\
\text { Implementation }\end{array}$ & CIETAC Online Arbitration Rule (CIETAC OAR). & $\begin{array}{l}\text { ODR for Regulation Consumer Disputes } \\
\text { Number } 542 / 2013 \text {. }\end{array}$ \\
\hline 3. & Competence & $\begin{array}{l}\text { a. Generally, it handles disputes arising from } \\
\text { economic and trade activities; } \\
\text { b. Special competencies held by CIETAC is in } \\
\text { the form of "domain name" dispute resolution } \\
\text { services }\end{array}$ & $\begin{array}{l}\text { The EC has the authority to hold trade dispute } \\
\text { settlement between countries belonging to the } \\
\text { European Union. }\end{array}$ \\
\hline 4. & $\begin{array}{l}\text { Dispute } \\
\text { Resolution } \\
\text { Method }\end{array}$ & $\begin{array}{l}\text { Arbitration that is combined with mediation and } \\
\text { conciliation methods }\end{array}$ & $\begin{array}{l}\text { Disputing parties are given the freedom to } \\
\text { choose the method of dispute resolution }\end{array}$ \\
\hline 5. & $\begin{array}{l}\text { Dispute } \\
\text { Resolution } \\
\text { Method }\end{array}$ & $\begin{array}{l}\text { Below are the stages of the dispute resolution } \\
\text { process at CIETAC: } \\
\text { 1. Administration Process } \\
\text { a. Petition for Arbitration } \\
\text { b. Arbitration Notification } \\
\text { c. Arbitrator Assembly } \\
\text { d. Defendant Note and Reverse Lawsuit } \\
\text { e. Defendant's Note of Counter-suit } \\
\text { 2. Court Process } \\
\text { 3. Submission of Online Arbitration Decision }\end{array}$ & $\begin{array}{l}\text { Below are the stages of the dispute resolution } \\
\text { process at the EC: } \\
\text { 1. Internal Disputes Resolution (IDR); } \\
\text { 2. Complaints on the EC ODR platform; } \\
\text { 3. Confirmation of Complaints; } \\
\text { 4. The selection of dispute resolution } \\
\text { institutions, followed by the business } \\
\text { actors; } \\
\text { 5. Dispute resolution process. } \\
\text { 6. Decision on Disputes }\end{array}$ \\
\hline 6. & Final Verdict & $\begin{array}{l}\text { The decision is made in written form containing } \\
\text { the date the decision was made and the place } \\
\text { where the decision was made, and signed by the } \\
\text { arbitrator. It also uses the official label of CIETAC. }\end{array}$ & $\begin{array}{l}\text { Decisions are made in written form and } \\
\text { informed to the parties by e-mail. EC } \\
\text { decisions have no legal force. }\end{array}$ \\
\hline
\end{tabular}

Currently, the ODR development in Indonesia has been initiated by BPKN (National Consumer Protection Agency) which is now building a National Consumer Complaints Information System. This was stated by BPKN chairman, Ardiansyah Parman, at the National Seminar on "Consumer Protection in the Era of the Industrial Revolution 4.0" organized by the Faculty of Law, Jember University, in collaboration with BPKN, on March 11, 2020. In the future, this complaint system can be used as a place to register complaints if consumers feel that their rights are violated by the business actors.
Furthermore, BPKN will verify whether the complaint meets the elements of consumer disputes or not. If it meets the complaint, it will be forwarded to BPSK for the actual dispute resolution process. BPSK then conducts the dispute resolution process from the beginning until the dispute resolution decision is issued.

\section{CONCLUSION}

Based on the description above, given the rapid pace of technological development, it can be concluded that the conception for future 
regulations on online dispute resolution as an alternative dispute resolution of electronic commerce transactions can only be materialised by the two methods.

First, by appointing a particular institution (BPSK) to handle the implementation of ODR. Second, by forming a new institution as an ODR provider. And then for the follow-up to the issuance of the PP PMSE.

\section{NOTES}

1 See at Hill, Richard dan Ian Walden dalam The Draft UNCITRAL Model Law for Electronic commerce: Issues and solutions (teaching materials) March 1996.

2 Onno W. Purbo dan Aang Arif Wahyudi, Mengenal E-Commerce, (Jakarta: Elex Media Komputindo, 2001), p. 1-2.

3 Widaningsih, Penyelesaian Sengketa E-Commerce, (Jurnal Panorama Hukum, Vol .2, No. 2, Edisi Desember 2017), p. 244.

$4 \quad$ Ibid.,p. 245.

5 Elsi Kartika Sari dan Advendi Simangunson, Hukum Dalam Ekonomi, (Jakarta: Grasindo, 2005), p. 154.

6 Gatot Sumartono, Arbitase Dan Mediasi Di Indonesia, (Jakarta: PT Gramedia Pustaka Utama, 2006), p. 4.

7 Otoritas Jasa Keuangan (Departemen Perlindungan Konsumen), Kajian Perlindungan Konsumen Sektor Jasa Keuagan: Online Dispute Resolution (ODR), (Jakarta: OJK, 2017), p. 4.

8 Pablo Cortes, Online Dispute Resolution for Consumers: Online Dispute Resolution Methods for Settling Businesses to Consumer Conflicts, (Oapen, 2007) http://www.mediate.com/pdf/ cortes.pdf, acsesed at tanggal 25 November 2019.

9 Hutrin Kamil dan M. Ali Masyur, Kajian Hukum Online Dispute Resolution (ODR) di Indonesia Berdasarkan Undang-Undang Nomor 30 Tahun 1999, (Jurnal Pembaharuan Hukum, Volume I No. 2 Mei-Agustus 2014), p. 111.

10 Otoritas Jasa Keuangan (Departemen Perlindungan Konsumen), Op.cit., p. 37.

11 Dyah Ochtorina Susanti dan A'an Efendi, Penelitian Hukum (Legal Research), (Jakarta: Sinar Grafika, 2014), p. 52. Primary legal materials are binding legal materials, for example laws, and regulations. Related to secondary legal materials include law books, legal dictionaries, journals, and so forth.

12 Soejono dan Abdurrahman, Metode Penelitian Hukum, (Jakarta: Rineka Cipta, 2003), p. 56.

13 Dyah Ochtorina Susanti dan A'an Efendi, Op.Cit., p. 11.
14 Peter Mahmud Marzuki, Penelitian Hukum, (Jakarta: Prenada Media, 2005), p. 93.

15 Jhonny Ibrahim, Teori dan Metodologi Penelitian Hukum Normatif, (Malang: Bayu Media Publising, 2008), p. 173.

16 Sri Hajati dkk, Politik Hukum Pertanahan, (Surabya: Airlangga University Press, 2018)., p. 433.

17 Goodman, Joseph W., n. d., The Pros and Cons of Online Dispute Resolution: An Assessment of Cyber-Mediation Websites., p.2-5.

\section{REFERENCES}

CIETAC Online Arbitration Rules (CIETAC OAR). Dyah Ochtorina Susanti \& A'an Efendi. 2013. Penelitian Hukum (Legal Reearch). Jakarta: Sinar Grafika.

European Commission ODR for Regulation Consumer Disputes Number 542/2013.

Elsi Kartika Sari \& Advendi Simangunson. 2005. Hukum Dalam Ekonomi. Jakarta: Grasindo.

Gatot Sumartono. 2006. Arbitase Dan Mediasi di Indonesia. Jakarta: PT Gramedia Pustaka Utama.

Hill, Richard dan Ian Walden dalam The Draft UNCITRAL Model Law for Electronic commerce: Issues and solutions (teaching materials) March 1996.

Hutrin Kamil \& M. Ali Masyur. 2014. Kajian Hukum Online Dispute Resolution (ODR) di Indonesia Berdasarkan Undang-Undang Nomor 30 Tahun 1999. Jurnal Pembaharuan Hukum 1(2) Mei-Agustus 2014.

Jhonny Ibrahim. 2008. Teori dan Metodologi Penelitian Hukum Normatif. Malang: Bayu Media Publising.

Onno W. Purbo \& Aang Arif Wahyudi. 2001. Mengenal E-Commerce. Jakarta: Elex Media Komputindo.

Otoritas Jasa Keuangan (Departemen Perlindungan Konsumen). 2017. Kajian Perlindungan Konsumen Sektor Jasa Keuagan: Online Dispute Resolution (ODR). Jakarta: OJK.

Peter Mahmud Marzuki. 2005. Penelitian Hukum. Jakarta: Prenada Media Group.

Pablo Cortes. 2007. Online Dispute Resolution for Consumers: Online Dispute Resolution Methods for Settling Businesses to Consumer Conflicts, Oapen.

Peraturan Pemerintah Nomor 80 Tahun 2019 Tentang Perdagangan Melalui Sistem Elektronik (Lembaran Negara Republik 
Indonesia Tahun 2019 Nomor 222, Tambahan Lembaran Negara Republik Indonesia Nomor 6420)

Soejono \& Abdurrahman. 2003. Metode Penelitian Hukum. Jakarta: Rineka Cipta.

Sri Hajati dkk. 2018. Politik Hukum Pertanahan. Surabya: Airlangga University Press.

Undang-Undang Nomor 30 tahun 1999 tentang Arbitrase dan Alternatif Penyelesaian Sengketa (Lembaran Negara Republik Indonesia Tahun 1999 Nomor 138, Tambahan Lembaran Negara Republik Indonesia Nomor 3872).

Undang-Undang Nomor 11 Tahun 2008 Tentang Informasi dan Transaksi Elektronik (Lembaran Negara Republik Indonesia Tahun 2008 Nomor 58, Tambahan Lembaran Negara Republik Indonesia Nomor 4843)
Undang-Undang Nomor 7 Tahun 2014 Tentang Perdagangan (Lembaran Negara Republik Indonesia Tahun 2014 Nomor 45, Tambahan Lembaran Negara Republik Indonesia Nomor 5512).

Widaningsih. 2017. Penyelesaian sengketa e-commerce. Jurnal Panorama Hukum 2(2) Edisi Desember 2017.

Rahmadi Indra Tektona

Fakultas Hukum

Universitas Jember

Indonesia

Emel: rahmadiindra@unej.ac.id

Ayudya Rizqi Rachmawati

Fakultas Hukum

Universitas Jember

Indonesia 